\title{
Urgensi Pembentukan Aturan Terkait Pencegahan Covid-19 di Indonesia
}

\author{
Dalinama Telaumbanua \\ Sekolah Tinggi Ilmu Hukum Nias Selatan \\ dalitelaumbanua@gmail.com
}

Naskah diterima: 11 Maret 2020| Naskah disetujui: 22 Maret 2020

\begin{abstract}
Covid-19 is a contagious disease that has the potential to cause a public health emergency. Therefore, preventive measures against these types of infectious diseases are mandatory as soon as possible. Indonesia as a nation of law, the prevention of infectious diseases is mandatory to be formed in a rule or regulation. The urgency of forming rules related to the prevention of Covid-19 is obliged to be formed in government regulation and regulation of the Minister of Health because both regulations are the implementation rules of Law No. 6 of 2018 concerning Health. Based on the author's analysis, there are 5 government regulations that must be established in order to perform countermeasures and prevention of infectious disease threats such as Covid-19 and there are 11 mandatory ministerial health regulations that are required to be established In anticipation of the Covid-19 threat. Both types of regulations are very useful in anticipating health emergency that ultimately leads to the health of Indonesian people. It is expected that both of rules can be made immediately in order to give legal certainty in preventing the spread of Covid-19 widely.
\end{abstract}

Keywords: Forming Rules, Management, Covid-19

\begin{abstract}
Abstrak
Covid-19 merupakan penyakit menular yang berpotensi menimbulkan kedaruratan kesehatan masyarakat. Oleh sebab itu, tindakan pencegahan terhadap jenis penyakit menular tersebut wajib dilakukan secepat mungkin. Indonesia sebagai negara hukum, maka pencegahan terhadap jenis penyakit menular tersebut wajib dibentuk dalam sebuah aturan atau regulasi. Urgensi pembentukan aturan terkait dengan pencegahan Covid-19 ini wajib dibentuk dalam Peraturan Pemerintah dan Peraturan Menteri Kesehatan karena kedua peraturan tersebut merupakan peraturan pelaksanaan daripada Undang-Undang Nomor 6 Tahun 2018 tentang Kekarantinaan Kesehatan. Berdasarkan analisis penulis, ada 5 Peraturan Pemerintah yang wajib dibentuk dalam rangka melakukan tindakan penanggulangan dan pencegahan ancaman penyakit yang mudah menular seperti Covid19 dan ada 11 Peraturan Menteri Kesehatan terkait yang wajib dibentuk dalam rangka mengantisipasi ancaman Covid-19. Kedua jenis peraturan tersebut sangat berguna dalam hal mengantisipasi kedaruratan kesehatan yang pada akhirnya menjurus pada kekarantinaan kesehatan masyarakat Indonesia. Kiranya kedua jenis peraturan ini segera dibuat dalam rangka memberi kepastian hukum dalam mencegah menularnya Covid-19 secara meluas.
\end{abstract}

Kata Kunci: Pembentukan Aturan, Penanggulangan, Covid-19 


\section{Pendahuluan}

Menularnya Covid-19 membuat dunia menjadi resah, termasuk di Indonesia. Covid-19 merupakan jenis virus yang baru sehingga banyak pihak yang tidak tahu dan tidak mengerti cara penanggulangan virus tersebut. Seiring mewabahnya virus Corona atau Covid-19 ke ratusan negara, Pemerintah Republik Indonesia menerbitkan protokol kesehatan. Protokol tersebut akan dilaksanakan di seluruh Indonesia oleh pemerintah dengan dipandu secara terpusat oleh Kementerian Kesehatan RI (2020).

Sampai pada penjelasan dan tata cara penanganan tersebut tidak ada persoalan, namun ternyata Covid-19 terus menular secara meluas dan seakan tidak bisa tertangani sehingga membuat Ketua DPR RI berkali-kali mengingatkan pemerintah agar segera membentuk tim nasional penanganan wabah virus korona yang bersifat terpusat (CNN Indonesia, 2020). Selain itu, karena kurangnya informasi membuat masyarakat di berbagai daerah banyak yang mengeluh, bingung dan semakin khawatir akibat tidak mendapatkan pelayanan secara aman dan meyakinkan ketika merasa ada indikasi terpapar virus Covid-19.

Masalah lain yang muncul adalah terkait pihak yang berwenang dalam menetapkan kedaruratan kesehatan masyarakat, apakah pemerintah pusat ataupun pemerintah daerah. Walaupun Presiden telah menegaskan bahwa kebijakan lockdown tidak boleh diambil oleh pemerintah daerah, namun bisa saja kepala daerah mengambil kebijakan lockdown jika memang menurut kepala daerah itu wajib dilakukan. Jika memang pemerintah daerah mengambil kebijakan tersebut bisa jadi banyak pihak yang menganggap itu salah karena tidak sesuai dengan ketentuan undangundang, namun kalau respons pemerintah pusat lambat dan juga karena lemahnya regulasi maka tindakan tersebut dianggap hal yang lumrah dalam menghadapi ancaman darurat seperti Covid-19 ini.

Kemudian persoalan lainnya yang muncul yakni pemerintah dituntut untuk sesegera mungkin menangani ancaman nyata Covid-19. Jawaban sementara terkait dengan persoalan tersebut ternyata telah ada dalam Undang-Undang Nomor 6 Tahun 2018 tentang Kekarantinaan Kesehatan (selanjutnya dalam tulisan ini disebut UU Kekarantinaan Kesehatan). Dimana dalam undang-undang tersebut telah memuat banyak hal terkait dengan kekarantinaan kesehatan, pihak yang berwenang menetapkan kedaruratan kesehatan masyarakat, dan lain sebagainya. Dalam undang-undang tersebut juga menentukan apa saja peraturan pelaksanaan sebagai tindak lanjut ketentuan dalam kekarantinaan kesehatan. Namun berdasarkan observasi awal penulis menemukan bahwa peraturan pelaksanaan sebagai ketentuan lanjutan dari UU Kekarantinaan Kesehatan belum ada padahal peraturan pelaksanaan tersebut sangat perlu untuk segera dibentuk.

Berdasarkan uraian tersebut, maka penulis tertarik untuk melakukan penelitian dengan judul Urgensi Pembentukan Aturan Terkait Pencegahan Covid-19 di Indonesia. Adapun tujuan penulisan ini yaitu untuk mengetahui dan menganalisis urgensi pembentukan aturan hukum di Indonesia terkait pencegahan Covid-19. Jenis penelitian yang digunakan penulis dalam artikel ini yaitu jenis penelitian hukum normatif dengan menggunakan ketiga bahan hukum yakni bahan hukum primer, sekunder, dan tersier. Ketiga bahan hukum tersebut dianalisis secara kualitatif dan disimpulkan dengan cara deduktif. 


\section{Hasil dan Pembahasan}

\section{Hasil}

Berdasarkan hasil penelitian terhadap ketentuan Undang-Undang Nomor 6 Tahun 2018 tentang Kekarantinaan Kesehatan menemukan bahwa ada beberapa peraturan pelaksana dari undang-undang tersebut yang wajib dibentuk yaitu Pasal 10 ayat (4), Pasal 11 ayat (3), Pasal 14 ayat (2), Pasal 15 ayat (4), Pasal 19 ayat (6), Pasal 24, Pasal 30 ayat (4), Pasal 32, Pasal 35 ayat (5), Pasal 47, Pasal 48 ayat (6), Pasal 60, Pasal 70, Pasal 75 ayat (4), Pasal 77 ayat (3), Pasal 82 ayat (4), dan Pasal 83 ayat (3). Dari 17 pasal tersebut, jenis peraturan perundang-undangan yang disinggung yakni Peraturan Pemerintah dan Peraturan Menteri Kesehatan.

\section{Pembahasan}

Dalam rangka menjawab rumusan masalah tentang urgensi pembentukan aturan terkait pencegahan Covid-19, maka penulis mendasarkan pada beberapa ketentuan yang ada dalam Undang-Undang Nomor 6 Tahun 2018 tentang Kekarantinaan Kesehatan. Dalam undang-undang tersebut, ada beberapa ketentuan yang memerintahkan dibentuknya peraturan perundang-undangan yang lain, yaitu dalam bentuk peraturan pemerintah dan peraturan menteri kesehatan.

a. Peraturan Pemerintah

1) Peraturan Pemerintah tentang Tata Cara Penetapan dan Pencabutan Kedaruratan Kesehatan Masyarakat

Sesuai dengan ketentuan dalam Pasal 10 UU Kekarantinaan Kesehatan menentukan bahwa pemerintah pusat menetapkan dan mencabut kedaruratan kesehatan masyarakat. Kedaruratan kesehatan masyarakat menurut Pasal 1 angka 2 UU Kekarantinaan Kesehatan yaitu kejadian kesehatan masyarakat yang bersifat luar biasa dengan ditandai penyebaran penyakit menular dan/atau kejadian yang disebabkan oleh radiasi nuklir, pencemaran biologi, kontaminasi kimia, bioterorisme, dan pangan yang menimbulkan bahaya kesehatan dan berpotensi menyebar lintas wilayah atau lintas negara.

Pemerintah pusat juga berwenang menetapkan dan mencabut penetapan pintu masuk dan/atau wilayah di dalam negeri yang terjangkit kedaruratan kesehatan masyarakat. Pintu masuk menurut Pasal 1 angka UU Kekarantinaan Kesehatan adalah "tempat masuk dan keluarnya alat angkut, orang, dan/atau barang, baik berbentuk pelabuhan, bandar udara, maupun pos lintas batas darat negara”.

Sebelum menetapkan kedaruratan kesehatan masyarakat, pemerintah pusat terlebih dahulu menetapkan jenis penyakit dan faktor risiko yang dapat menimbulkan kedaruratan kesehatan masyarakat. Seperti informasi dan kejadian pada awal tahun 2020 ini, jenis penyakit yang sangat meresahkan dunia internasional yaitu Covid-19. Pemerintah Indonesia menjelaskan bahwa ada dua mekanisme virus corona yaitu menyerang organ tubuh manusia hingga mengakibatkan kematian (CNN Indonesia, 2020). Oleh sebab itu, jenis penyakit seperti ini dikategorikan sebagai kedaruratan kesehatan masyarakat sehingga perlu adanya penetapan secara resmi dari pemerintah tentang kedaruratan kesehatan masyarakat dan juga cara pencabutan kedaruratan kesehatan masyarakat. 
Oleh sebab itu, perlu sesegera mungkin dibuat peraturan pemerintah tentang tata cara penetapan dan pencabutan kedaruratan kesehatan masyarakat karena kewenangan tersebut merupakan kewenangan pemerintah pusat karena hal tersebut telah diatur dalam Pasal 10 ayat (4) UU Kekarantinaan Kesehatan.

2) Peraturan Pemerintah tentang Penanggulangan Kedaruratan Kesehatan Masyarakat

Berdasarkan ketentuan dalam Pasal 11 UU Kekarantinaan Kesehatan menentukan bahwa penyelenggaraan kekarantinaan kesehatan pada kedaruratan kesehatan masyarakat dilaksanakan oleh pemerintah pusat secara cepat dan tepat berdasarkan besarnya ancaman, efektivitas, dukungan sumber daya, dan teknik operasional dengan mempertimbangkan kedaulatan negara, keamanan, ekonomi, sosial, dan budaya. Penyelenggaraan kekarantinaan kesehatan tersebut, pemerintah pusat dapat berkoordinasi dan bekerja sama dengan dunia internasional. Seperti yang telah dicantumkan sebelumnya bahwa ancaman Covid-19 sudah sangat masif tersebar di seluruh dunia dan pemerintah Indonesia juga telah berkoordinasi dengan dunia internasional terkait dengan cara penanganan ancaman penyakit tersebut. hanya saja, sampai tulisan ini dibuat pemerintah Indonesia belum membentuk peraturan pemerintah tentang penanggulangan jenis penyakit tersebut karena jenis penyakit tersebut sudah layak dikategorikan sebagai kedaruratan kesehatan masyarakat. Padahal menurut ketentuan dalam Pasal 11 ayat (3) UU Kekarantinaan Kesehatan mencantumkan bahwa "penanggulangan kedaruratan kesehatan masyarakat diatur dengan Peraturan Pemerintah." Oleh karena itu, sudah selayaknya pemerintah Indonesia sesegera mungkin membentuk Peraturan Pemerintah tentang penanggulangan kedaruratan kesehatan masyarakat.

3) Peraturan Pemerintah tentang Tata Cara Pelaksanaan Karantina Wilayah di Pintu Masuk

Dalam keadaan kedaruratan kesehatan masyarakat yang meresahkan dunia, pemerintah pusat dapat menetapkan karantina wilayah di pintu masuk. Berdasarkan informasi yang tersebar di banyak media, antara lain IDN Times Bali (2020) menyatakan bahwa Covid-19 berasal dari Wuhan, Tiongkok, dan virus tersebut telah tersebar di berbagai negara, maka Pemerintah Indonesia perlu membuat karantina wilayah. Karantina wilayah adalah "pembatasan penduduk dalam suatu wilayah termasuk wilayah pintu masuk beserta isinya yang diduga terinfeksi penyakit dan/atau terkontaminasi sedemikian rupa untuk mencegah kemungkinan penyebaran penyakit atau kontaminasi" (Pasal 1 angka 10 UU Kekarantinaan Kesehatan). Karantina wilayah dilakukan dalam rangka mencegah Covid-19 masuk ke Indonesia karena Covid-19 ini gampang terinfeksi kepada orang lain melalui pernafasan dan melalui sentuhan badan. Dengan demikian, warga negara asing maupun warga negara Indonesia yang berasal dari luar dan berdatangan ke Indonesia perlu diperiksa apakah yang bersangkutan telah terjangkit atau tidak Covid-19. Pembatasan utama terkait dengan karantina wilayah ini wajib dilakukan di pintu masuk baik di pelabuhan, bandar udara, maupun pos lintas batas darat negara.

Tentunya efektif tidaknya karantina wilayah ini ketika ada standar pemeriksaan dari pemerintah Indonesia. Hal ini didasarkan pada ketentuan Pasal 14 ayat (2) UU Kekarantinaan Kesehatan yang menentukan bahwa "ketentuan tata cara pelaksanaan karantina wilayah di pintu masuk diatur dengan Peraturan Pemerintah”. 
4) Peraturan Pemerintah tentang Tata Cara Pengenaan Sanksi Administratif Kepada Nakhoda, Kapten Penerbang, dan Pengemudi Terkait Dokumen Karantina Kesehatan.

Sanksi administratif ini telah diatur dalam ketentuan Pasal 48 UU Kekarantinaan Kesehatan yang dikenakan kepada:

a) Nakhoda

Nakhoda kapal yang datang dari luar negeri, datang dari pelabuhan wilayah terjangkit di dalam negeri, atau mengambil orang dan/atau barang dari kapal berada dalam status karantina wajib memberikan Deklarasi Kesehatan Maritim kepada pejabat karantina kesehatan pada saat kedatangan kapal. Setiap nakhoda yang tidak memberikan deklarasi kesehatan maritim tersebut dikenai sanksi administratif berupa peringatan, denda administratif dan/atau pencabutan izin.

b) Kapten Penerbang

Setiap Kapten Penerbang yang tidak memberikan Deklarasi Kesehatan Penerbangan dikenai sanksi administratif berupa peringatan, denda administratif, dan/atau pencabutan izin.

c) Pengemudi

Setiap pengemudi atau penanggung jawab kendaraan darat yang tidak melengkapi Dokumen Karantina Kesehatan sehingga tidak diberikan persetujuan Karantina Kesehatan dikenai sanksi administratif berupa peringatan, denda administratif dan/atau pencabutan izin.

Berdasarkan ketiga poin tersebut dan juga didasarkan pada ketentuan dalam Pasal 48 ayat (6) UU Kekarantinaan Kesehatan, maka sudah semestinya sesegera mungkin dibentuk Peraturan Pemerintah tentang Tata Cara Pengenaan Sanksi Administratif Kepada Nakhoda, Kapten Penerbang, dan Pengemudi Terkait Dokumen Karantina Kesehatan.

5) Peraturan Pemerintah tentang Kriteria dan Pelaksanaan Karantina Rumah, Karantina Wilayah, Karantina Rumah Sakit, dan Pembatasan Sosial Berskala Besar

Berdasarkan persebaran Covid-19 yang semakin luas dan berskala besar, maka sudah semestinya dilakukan karantina rumah, karantina wilayah, karantina rumah sakit, dan/atau pembatasan sosial berskala besar.

a) Karantina rumah menurut Pasal 1 angka 8 UU Kekarantinaan Kesehatan adalah "pembatasan penghuni dalam suatu rumah beserta isinya yang diduga terinfeksi penyakit dan/atau terkontaminasi sedemikian rupa untuk mencegah kemungkinan penyebaran penyakit atau kontaminasi."

b) Karantina wilayah menurut Pasal 1 angka 10 UU Kekarantinaan Kesehatan adalah "pembatasan penduduk dalam suatu wilayah termasuk wilayah pintu masuk beserta isinya yang diduga terinfeksi penyakit dan/atau terkontaminasi sedemikian rupa untuk mencegah kemungkinan penyebaran penyakit atau kontaminasi."

c) Karantina rumah sakit menurut Pasal 1 angka 9 UU Kekarantinaan Kesehatan adalah "pembatasan seseorang dalam rumah sakit yang diduga terinfeksi penyakit dan/atau terkontaminasi sedemikian rupa untuk mencegah kemungkinan penyebaran penyakit atau kontaminasi."

d) Pembatasan sosial berskala besar menurut Pasal 1 angka UU Kekarantinaan Kesehatan adalah "pembatasan kegiatan tertentu penduduk dalam suatu wilayah 
yang diduga terinfeksi penyakit dan/atau terkontaminasi sedemikian rupa untuk mencegah kemungkinan penyebaran penyakit atau kontaminasi."

Presiden Republik Indonesia menggarisbawahi pentingnya mengurangi mobilitas orang dari satu tempat ke tempat lainnya, melakukan pembatasan sosial (social distancing), serta mengurangi kerumunan yang membawa risiko penyebaran Covid19 (Kementerian Sekretariat Negara RI, 2020).

Berdasarkan keempat poin tersebut dan juga didasarkan pada ketentuan dalam Pasal 60 UU Kekarantinaan Kesehatan, maka sudah semestinya sesegera mungkin dibentuk Peraturan Pemerintah tentang Kriteria dan Pelaksanaan Karantina Rumah, Karantina Wilayah, Karantina Rumah Sakit, dan Pembatasan Sosial Berskala Besar.

b. Peraturan Menteri Kesehatan

1) Peraturan Menteri Kesehatan tentang Tindakan Kekarantinaan Kesehatan di Pintu Masuk

Kekarantinaan kesehatan di pintu masuk dan di wilayah dilakukan melalui kegiatan pengamatan penyakit dan faktor risiko kesehatan masyarakat (hal, keadaan, atau peristiwa yang dapat mempengaruhi kemungkinan timbulnya pengaruh buruk terhadap kesehatan masyarakat) terhadap alat angkut (kapal, pesawat udara, dan kendaraan darat), orang, barang, dan/atau lingkungan, serta respons terhadap kedaruratan kesehatan masyarakat dalam bentuk tindakan kekarantinaan kesehatan. Tindakan kekarantinaan kesehatan terhadap kegiatan tersebut antara lain berupa:

a) Karantina merupakan pembatasan kegiatan dan/atau pemisahan seseorang yang terpapar penyakit menular sebagaimana ditetapkan dalam peraturan perundangundangan meskipun belum menunjukkan gejala apapun atau sedang berada dalam masa inkubasi, dan/atau pemisahan peti kemas, alat angkut, atau barang apapun yang diduga terkontaminasi dari orang dan/atau barang yang mengandung penyebab penyakit atau sumber bahan kontaminasi lain untuk mencegah kemungkinan penyebaran ke orang dan/atau barang di sekitarnya.

b) Isolasi merupakan pemisahan orang sakit dari orang sehat yang dilakukan di fasilitas pelayanan kesehatan untuk mendapatkan pengobatan dan perawatan.

Tindakan kekarantinaan kesehatan tersebut wajib dibuat dalam bentuk Peraturan Menteri Kesehatan supaya jelas tindakan apa yang akan diambil atau dilakukan salah satunya terhadap upaya pencegahan Covid-19. Keharusan membuat Peraturan Menteri Kesehatan ini telah dimuat dalam sebagaimana tercantum dalam Pasal 15 ayat (4) UU Kekarantinaan Kesehatan.

2) Peraturan Menteri Kesehatan tentang Tata Laksana Pengawasan Kekarantinaan Kesehatan di Pelabuhan

Nakhoda kapal yang datang dari luar negeri, datang dari pelabuhan wilayah terjangkit di dalam negeri atau mengambil orang dan/atau barang dari kapal berada dalam status karantina hanya dapat menurunkan atau menaikkan orang dan/atau barang setelah dilakukan pengawasan kekarantinaan kesehatan oleh pejabat karantina kesehatan. Yang dimaksud dengan pengawasan kekarantinaan kesehatan adalah "kegiatan pemeriksaan dokumen karantina kesehatan dan faktor risiko kesehatan masyarakat terhadap alat angkut, orang, serta barang oleh pejabat karantina 
kesehatan" (Pasal 1 angka 25 UU Kekarantinaan Kesehatan). Sedangkan pejabat karantina kesehatan merupakan PNS yang bekerja di bidang kesehatan yang diberi kewenangan oleh menteri yang menyelenggarakan urusan pemerintahan di bidang kesehatan untuk melaksanakan kekarantinaan kesehatan.

Regulasi terkait dengan tata laksana pengawasan kekarantinaan kesehatan tersebut wajib dimuat dalam Peraturan Menteri Kesehatan karena hal tersebut telah ditegaskan dalam Pasal 19 ayat (6) UU Kekarantinaan Kesehatan.

3) Peraturan Menteri Kesehatan tentang Kekarantinaan Kesehatan terhadap Kapal Perang, Kapal Negara, dan Kapal Tamu Negara

Oleh karena Covid-19 berasal dari negara Tiongkok dan juga karena telah terjangkit kepada beberapa orang di berbagai negara, maka untuk memutus rantai tersebut wajib dilakukan karantina terhadap kapal perang, kapal negara, dan kapal tamu negara yang akan datang ke Indonesia. Karena kemungkinan, penghuni kapal tersebut telah terjangkit virus korona. Lalu kekarantinaan terhadap ketiga jenis kapal tersebut agak berbeda dengan kekarantinaan kapal pada umumnya. Hal ini dilakukan karena itu terkait dengan kapal perang yang tidak sembarangan untuk diperiksa, kapal negara asing yang juga tidak sembarangan untuk diperiksa, serta kapal tamu negara yang wajib dihormati dan dijaga kerahasiaannya. Kekarantinaan kesehatan terhadap ketiga jenis kapal tersebut, Menteri Kesehatan wajib berkoordinasi dengan menteri lain karena ketiga kepentingan kapal tersebut ada kaitannya dengan Kementerian yang lain.

Oleh sebab itu, penanganan khusus ini wajib dimuat dalam Peraturan Menteri Kesehatan tentang Kekarantinaan Kesehatan Terhadap Kapal Perang, Kapal Negara, dan Kapal Tamu Negara (Pasal 24 UU Kekarantinaan Kesehatan).

4) Peraturan Menteri Kesehatan tentang Tata Laksana Pengawasan Kekarantinaan Kesehatan di Bandar Udara

Berdasarkan ketentuan dalam Pasal 30 ayat (1) UU Kekarantinaan Kesehatan menegaskan bahwa "kapten penerbang pada pesawat udara hanya dapat menurunkan atau menaikkan orang dan/atau barang setelah dilakukan pengawasan kekarantinaan kesehatan oleh pejabat karantina kesehatan." Pesawat udara yang dimaksud yaitu yang datang dari luar negeri, datang dari bandar udara wilayah yang terjangkit penyakit yang gampang menular, terdapat orang hidup atau mati yang diduga terjangkit penyakit yang gampang menular, dan/atau terdapat orang dan/atau barang diduga terpapar yang gampang menular di dalam pesawat udara berada dalam status karantina. Kapten penerbang terhadap pesawat tersebut wajib segera melaporkan keadaan tersebut kepada petugas lalu lintas udara untuk diteruskan kepada pejabat karantina kesehatan di bandar udara tujuan dengan menggunakan teknologi telekomunikasi.

Pengawasan kekarantinaan kesehatan di bandar udara terdapat pesawat udara tersebut dilakukan dalam rangka untuk memperoleh persetujuan karantina kesehatan sehingga perlu adanya persetujuan karantina kesehatan berupa persetujuan bebas karantina dan/atau persetujuan karantina terbatas.

Oleh karena pentingnya pengawasan kekarantinaan kesehatan di bandar udara serta karena berhubungan dengan pesawat udara yang salah satunya berasal dari luar negeri, maka perlu dibentuk Peraturan Menteri Kesehatan tentang Tata Laksana Pengawasan 
Kekarantinaan Kesehatan di Bandar Udara. Pembentukan Peraturan Menteri Kesehatan ini telah dicantumkan dalam Pasal 30 ayat (4) UU Kekarantinaan Kesehatan.

5) Peraturan Menteri Kesehatan tentang Kekarantinaan Kesehatan terhadap Pesawat Udara Perang, Pesawat Udara Negara, dan Pesawat Udara Tamu Negara

Ketika penyakit yang mudah menular seperti Covid-19 yang notabene berasal dari negara Tiongkok dan juga karena telah menular kepada beberapa orang di berbagai negara, maka sudah semestinya ada upaya serius untuk menangkal penyakit tersebut dengan cara mencegah penyakit tersebut menular di dalam negeri. Penularan ini dapat berasal salah satunya dari pesawat udara perang, pesawat udara negara, dan pesawat udara tamu negara. Ketika pesawat tersebut mendarat di Indonesia, maka upaya pemeriksaan oleh pihak kesehatan tidak sama dengan pemeriksaan pihak kesehatan terhadap pesawat yang lainnya. Karena tidak semudah ini memeriksa pesawat udara perang karena terkait dengan privasi suatu pesawat udara perang, tidak semudah itu juga memeriksa pesawat udara suatu negara yang mendarat di Indonesia karena terkait dengan asas teritorial negara asal pesawat udara tersebut, dan tidak semudah itu juga melakukan pemeriksaan terhadap pesawat udara tamu negara karena ini terkait dengan penghormatan terhadap tamu negara yang datang ke Indonesia.

Oleh karena itu, berdasarkan ketentuan dalam Pasal 32 UU Kekarantinaan Kesehatan menyatakan bahwa Menteri Kesehatan wajib berkoordinasi dengan menteri yang lain seperti Menteri Luar Negeri, Menteri Pertahanan, dan menteri terkait lainnya. Berdasarkan ketentuan tersebut, maka sudah seharusnya segera dibentuk Peraturan Menteri Kesehatan tentang Kekarantinaan Kesehatan Terhadap Pesawat Udara Perang, Pesawat Udara Negara, dan Pesawat Udara Tamu Negara.

6) Peraturan Menteri Kesehatan tentang Tindakan Kekarantinaan Kesehatan di Pos Lintas Batas Darat Negara

Dalam upaya untuk mencegah persebaran penyakit menular seperti Covid-19 di Indonesia terutama yang ditularkan oleh orang yang berasal dari luar negeri melalui perbatasan negara seperti batas Negara Indonesia dengan Negara Timor Leste dan Negara Malaysia, maka perlu pengawasan kendaraan darat sebelum menurunkan atau menaikkan orang dan/atau barang. Pengawasan terhadap kendaraan ini perlu diatur dalam suatu Peraturan Menteri Kesehatan supaya tidak terjadinya pelanggaran hak asasi manusia dan supaya tidak terjadinya pelanggaran hukum yang lain. Oleh sebab itu, regulasi khusus terkait dengan tindakan kekarantinaan kesehatan di pos lintas batas negara wajib dibentuk sesegera mungkin karena hal ini telah dicantumkan secara jelas dalam Pasal 35 ayat (5) UU Kekarantinaan Kesehatan.

7) Peraturan Menteri Kesehatan tentang Bentuk, Isi, Tata Cara Pengajuan dan Penerbitan serta Pembatalan Dokumen Karantina Kesehatan

Dokumen karantina kesehatan wajib dipunyai oleh setiap alat angkut, orang, dan barang yang masuk dan/atau keluar dari dalam atau luar wilayah negara Indonesia. Dokumen ini digunakan sebagai alat pengawasan dan pencegahan masuk dan/atau keluarnya penyakit dan faktor risiko kesehatan masyarakat yang menjadi sumber penularan penyakit seperti Covid-19. Melalui dokumen ini, dapat diketahui tentang penjelasan suatu keadaan yang diketahui secara pasti sebagai hasil dari pengawasan kekarantinaan kesehatan. 
Demi menjamin adanya kepastian terkait dengan dokumen ini, maka wajib dibentuk Peraturan Pemerintah tentang Bentuk, Isi, Tata Cara Pengajuan dan Penerbitan serta Pembatalan Dokumen Karantina Kesehatan.

8) Peraturan Menteri Kesehatan tentang Tata Cara Pelaksanaan Kewenangan Tindakan Kekarantinaan Kesehatan

Dengan semakin merebaknya Covid-19, maka menimbulkan juga polemik terkait dengan pembagian kewenangan pemerintah pusat dan kewenangan pemerintah daerah dalam tindakan kekarantinaan kesehatan. Dalam menjawab persoalan tersebut, Pasal 75 ayat (4) telah merumuskan bahwa tata cara pelaksanaan kewenangan tindakan kekarantinaan kesehatan diatur dalam Peraturan Menteri Kesehatan. Peraturan Menteri Kesehatan tersebut memuat antara lain:

a) Kewenangan pemerintah pusat mengatur penempatan pejabat karantina kesehatan di pintu masuk (pelabuhan, bandar udara, maupun pos lintas batas darat negara) dalam rangka penyelenggaraan kekarantinaan kesehatan.

b) Kewenangan pemerintah daerah mengatur penempatan pejabat karantina kesehatan di wilayah daerah yang dipimpinnya dalam rangka penyelenggaraan kekarantinaan kesehatan.

c) Kewenangan pejabat karantina kesehatan dalam hal:

(1) melakukan tindakan kekarantinaan kesehatan berupa:

(a) karantina, isolasi, pemberian vaksinasi atau profilaksis, rujukan, disinfeksi, dan/atau dekontaminasi terhadap orang sesuai indikasi. Khusus vaksinasi ini telah dilakukan telah dilakukan di Sekretariat Negara Republik Indonesia (https://setkab.go.id/cegah-penyebaran-covid-19-sekretariat-kabinet-

laksanakan-vaksinasi-influenza/). Hanya saja, vaksinasi ini tidak dilakukan di tempat lain sehingga hanya ada di suatu instansi atau wilayah tapi tidak ada di instansi atau wilayah lain.

(b) pembatasan sosial berskala besar.

(c) disinfeksi, dekontaminasi, disinseksi, dan/atau deratisasi terhadap alat angkut dan barang.

(d) penyehatan, pengamanan, dan pengendalian terhadap media lingkungan.

(2) menetapkan tindakan kekarantinaan kesehatan.

(3) menerbitkan surat rekomendasi deportasi atau penundaan keberangkatan kepada instansi yang berwenang.

(4) menerbitkan surat rekomendasi kepada pejabat yang berwenang untuk menetapkan karantina di wilayah.

9) Peraturan Menteri Kesehatan tentang Penelitian dan Pengembangan Penyelenggaraan Kekarantinaan Kesehatan

Penyakit yang diakibatkan oleh Covid-19 membuat dunia menjadi resah karena ini merupakan jenis virus baru sehingga dunia internasional termasuk Indonesia mendorong para pakar atau ahli di bidang kesehatan untuk segera melakukan tindakan karantina kesehatan sembari mencari obat yang tepat guna menyembuhkan penyakit yang mudah menular seperti Covid-19. Meskipun Covid-19 ini baru ada pada tahun 2019, namun sepertinya pembentuk undang-undang di Indonesia sudah menduga sejak awal bahwa akan ada penyakit yang berbahaya dan perlu dilakukannya tindakan kekarantinaan 
kesehatan sehingga pembentuk undang-undang telah merumuskan terkait dengan penelitian dan pengembangan penyelenggaraan kekarantinaan kesehatan diatur dalam suatu Peraturan Menteri Kesehatan dalam Pasal 77 ayat (3) UU Kekarantinaan Kesehatan.

Namun sayangnya Peraturan Menteri Kesehatan terkait dengan penelitian dan pengembangan tersebut belum ada yang cukup memadai untuk mengatur hal tersebut. Padahal penelitian dan pengembangan ini dimaksudkan sebagai upaya menapis dan menetapkan ilmu pengetahuan dan teknologi tepat guna dengan tetap memperhatikan kesehatan dan keselamatan masyarakat.

10) Peraturan Menteri Kesehatan tentang Pembinaan Penyelenggaraan Kekarantinaan Kesehatan

Kalau situasi penyakit yang mudah menular seperti Covid-19 sudah diputuskan oleh pemerintah Indonesia untuk dilakukannya kekarantinaan kesehatan, maka sangat penting dilakukannya pembinaan kepada pejabat karantina kesehatan. Pejabat karantina kesehatan ini merupakan tombak utama yang akan bertugas di lapangan. Sebagai tombak utama, maka sudah semestinya ada standar kerja yang akan dijadikan rujukan oleh para pejabat karantina kesehatan tersebut. Standar yang dimaksud dianggap sebagai suatu pembinaan kepada para pejabat tersebut. Selain itu melalui telekonferensi, Presiden Republik Indonesia menyatakan bahwa perlunya alat pelindung diri (APD) kepada tenaga medis karena tenaga medis atau pejabat karantina kesehatan berada di garis terdepan sehingga pejabat karantina kesehatan harus terlindung dan tidak terpapar Covid-19 (Kementerian Sekretariat Negara RI, 2020).

Sebagai sebuah standar yang akan dijadikan rujukan di seluruh wilayah Republik Indonesia, maka sudah seharusnya dibentuk dalam suatu Peraturan Menteri Kesehatan tentang Pembinaan Penyelenggaraan Kekarantinaan Kesehatan.

Keharusan membentuk peraturan ini telah dimuat dalam Pasal 82 ayat (4) UU Kekarantinaan Kesehatan. Materi muatan minimal yang wajib dimuat dalam peraturan tersebut yaitu:

a) Kewenangan pemerintah pusat melakukan pembinaan terhadap semua kegiatan yang berkaitan dengan penyelenggaraan kekarantinaan kesehatan di pintu masuk seperti bandar udara, pos lintas batas negara, dan pelabuhan.

b) Kewenangan pemerintah pusat melakukan pembinaan terhadap semua kegiatan yang berkaitan dengan penyelenggaraan kekarantinaan kesehatan di wilayah dengan melibatkan pemerintah daerah.

c) Tujuan pembinaan terhadap semua kegiatan yang berkaitan dengan penyelenggaraan kekarantinaan kesehatan baik di pintu masuk maupun di wilayah tersebut yaitu:

(1) meningkatkan mutu pelayanan dan profesionalisme pejabat karantina kesehatan sesuai dengan perkembangan ilmu pengetahuan dan teknologi dalam rangka kerja sama antarnegara secara bilateral, regional, maupun internasional.

(2) meningkatkan partisipasi masyarakat dalam menunjang peningkatan pelaksanaan kekarantinaan kesehatan.

(3) meningkatkan keterpaduan berbagai sektor terkait dalam rangka koordinasi dan kerja sama dalam menyelenggarakan kekarantinaan kesehatan. 
11) Peraturan Menteri Kesehatan tentang Pengawasan Penyelenggaraan Kekarantinaan Kesehatan

Hal lain yang wajib ada dalam penyelenggaraan kekarantinaan kesehatan setelah adanya pembinaan kepada pejabat karantina kesehatan yakni pengawasan. Pengawasan ini sangat penting dilakukan supaya kegiatan kekarantinaan kesehatan berjalan lancar dan efektif serta sesuai dengan prosedur yang telah ditentukan. Kewenangan pengawasan penyelenggaraan kekarantinaan kesehatan ini merupakan kewenangan pemerintah pusat dan pemerintah daerah.

Kewenangan pemerintah pusat yaitu melakukan pengawasan terhadap semua kegiatan yang berkaitan dengan penyelenggaraan kekarantinaan kesehatan di pintu masuk (pelabuhan, bandar udara, dan pos lintas batas darat negara), sedangkan kewenangan pemerintah daerah yaitu melakukan pengawasan terhadap kegiatan yang berkaitan dengan penyelenggaraan Kekarantinaan Kesehatan di daerah yang dipimpinnya baik di daerah provinsi maupun di daerah kabupaten atau kota.

Tentunya pembagian kewenangan ini akan tumpang tindih antar pemerintah pusat dan pemerintah daerah kalau tidak ada kejelasan. Oleh sebab itu, berdasarkan isi Pasal 83 ayat (3) UU Kekarantinaan Kesehatan perlu dibentuk Peraturan Menteri Kesehatan tentang Pengawasan Penyelenggaraan Kekarantinaan Kesehatan.

Untuk memenuhi kebutuhan masyarakat atas peraturan perundang-undangan yang baik, perlu dibuat peraturan mengenai pembentukan peraturan perundang-undangan yang dilaksanakan dengan cara dan metode yang pasti, baku, dan standar yang mengikat semua lembaga yang berwenang membentuk peraturan perundang-undangan (Dalinama, 2018). Peraturan Pemerintah dan Peraturan Menteri Kesehatan yang akan dibentuk ini juga merupakan bagian jenis peraturan perundang-undangan sehingga pembentukannya juga haris menggunakan cara dan metode yang pasti, baku, dan standar.

\section{Kesimpulan}

Berdasarkan uraian pada bagian pembahasan, maka dapat disimpulkan bahwa pembentukan aturan terkait pencegahan Covid-19 di Indonesia sangat penting dan mendesak untuk dilakukan dalam bentuk Peraturan Pemerintah dan Peraturan Menteri Kesehatan. Adapun beberapa Peraturan Pemerintah yang wajib dibentuk yaitu:

1. Tata Cara Penetapan dan Pencabutan Kedaruratan Kesehatan Masyarakat

2. Penanggulangan Kedaruratan Kesehatan Masyarakat

3. Tata Cara Pelaksanaan Karantina Wilayah di Pintu Masuk

4. Tata Cara Pengenaan Sanksi Administratif Kepada Nakhoda, Kapten Penerbang, dan Pengemudi terkait Dokumen Karantina Kesehatan

5. Kriteria dan Pelaksanaan Karantina Rumah, Karantina Wilayah, Karantina Rumah Sakit, dan Pembatasan Sosial Berskala Besar

Sedangkan Peraturan Menteri Kesehatan yang sesegera mungkin dibentuk yaitu:

1. Tindakan Kekarantinaan Kesehatan di Pintu Masuk

2. Tata Laksana Pengawasan Kekarantinaan Kesehatan di Pelabuhan

3. Kekarantinaan Kesehatan Terhadap Kapal Perang, Kapal Negara, dan Kapal Tamu Negara 
4. Tata Laksana Pengawasan Kekarantinaan Kesehatan di Bandar Udara

5. Kekarantinaan Kesehatan Terhadap Pesawat Udara Perang, Pesawat Udara Negara, dan Pesawat Udara Tamu Negara

6. Tindakan Kekarantinaan Kesehatan di Pos Lintas Batas Darat Negara

7. Bentuk, Isi, Tata Cara Pengajuan dan Penerbitan serta Pembatalan Dokumen Karantina Kesehatan

8. Tata Cara Pelaksanaan Kewenangan Tindakan Kekarantinaan Kesehatan

9. Penelitian dan Pengembangan Penyelenggaraan Kekarantinaan Kesehatan

10. Pembinaan Penyelenggaraan Kekarantinaan Kesehatan

11. Pengawasan Penyelenggaraan Kekarantinaan Kesehatan

\section{Referensi}

CNN Indonesia, (2020). DPR Desak Pemerintah Bentuk Satgas Penanganan Virus Corona. Available at: www.cnnindonesia.com/nasional/20200312020329-20-482683/dpr-desakpemerintah-bentuk-satgas-penanganan-virus-corona (Accessed: 20 Maret 2020).

IDN Times Bali, (2020). Asal Mula dan Penyebaran Virus Corona dari Wuhan ke Seluruh Dunia | IDN Times BALI. Available at: https://bali.idntimes.com/health/medical/dennyadhietya/asal-muasal-dan-perjalanan-virus-corona-dari-wuhan-ke-seluruh-dunia-regionalbali/full (Accessed: 20 Maret 2020).

Kementerian Kesehatan RI, (2020). Lakukan Protokol Kesehatan ini jika Mengalami Gejala Covid19 | Sehat Negeriku. Available at: http://sehatnegeriku.kemkes.go.id/baca/rilismedia/20200316/4033408/lakukan-protokol-kesehatan-jika-mengalami-gejala-covid-19/

(Accessed: 20 Maret 2020).

Kementerian Sekretariat Negara RI, (2020). Pemerintah Perhatikan Kebutuhan APD Bagi Tenaga Medis | Kementerian Sekretariat Negara RI. Available at:https://www.setneg.go.id/baca/index/pemerintah_perhatikan_kebutuhan_apd_bagi_tenag a_medis (Accessed: 20 Maret 2020).

Telaumbanua, D. (2018). "Pembentukan Peraturan Daerah Kabupaten/Kota." Jurnal Education and Development. vol. 4 , no. 1

Undang-Undang Republik Indonesia Nomor 6 Tahun 2018 tentang Kekarantinaan Kesehatan. 